\title{
Decomposition of Native Herbage and Filter Paper at Five Meadow Sites in Sequoia National Park, California
}

\author{
RAYMOND D. RATLIFF
}

\begin{abstract}
Rate of herbage decomposition may be related to maintenance and improvement of mountain meadows and may provide a guide to proper use. Weight losses from buried and unburied native herbage and filter paper were studied at five meadows in Sequoia National Park from 1972-1975. Aim of the study was to find a suitable technique for estimating and to obtain some estimates of decomposition of rates in meadows. Native herbage samples gave more precise measures of decomposition than did filter paper, and use of unburied herbage samples was accepted as the most preferred technique. Ranges of yearly weight losses and standard statistical errors for that technique were: losses, from $49 \%$ to $78 \%$ and errors, from $1.4 \%$ to $5.8 \%$.
\end{abstract}

Mountain meadows of the Sierra Nevada of California have been grazed by domestic as well as wild herbivores for many years. Overuse, primarily by sheep and cattle in the late 1800 's, resulted in deterioration of these meadows. Protection from grazing in National Parks and grazing management in National Forests in recent years have improved meadow condition in some areas. But the unresolved management question remains: What proportion of the current herbage production should be left to decompose (left unconsumed by the herbivore component) in order to maintain or improve meadow ecosystem?

The conventional approach to resolving such a question is through study of vegetation responses to various levels of stocking and degrees of use. Such studies are generally long-term and costly. Approaching the resolution through study of decomposition rates may reduce time and cost. For meadows of the Sierra Nevada, however, estimates of decomposition rates were not available and techniques for obtaining such estimates had not been assessed. The objective of this study, therefore, was to find a suitable tcchnique and to provide estimates of decomposition rates for a few meadow sites.

Various methods of studying decomposition are described by Dickinson and Pugh (1974). All methods of estimating decomposition rates currently being used are to some degree less than perfect. Therefore, one should not

\footnotetext{
The author is a range scientist with the Pacific Southwest Forest and Range Experiment Station, Forest Service, U.S. Department of Agriculture, Berkeley, Calif., stationed at 2081 E. Sierra Ave., Fresno, California, 93710.

ine auunor tnanks Ur. N.S. Urqunart (Uept. of Experimental Statistics, New Mexico State Univ., Las Cruces) for guidance in setting up the analyses; and Stanley E. Westfall, research range technician, Pacific Southwest Forest and Range Experiment Station, for assistance in planning the study and collecting the data.

Manuscript received November 20, 1978.
}

assume complete correspondence between estimated and actual decomposition rates.

The "litter bag" procedure is simple in principle and requires less equipment than procedures involving carbon dioxide evolution or loss rate from isotope labeled material. It is also practical in back country areas which can be visited only once a year. Hence, nylon bags with a 1-to 2-mm mesh were selected for use in this study. A known weight of vegetation is placed in a big, left to decompose for a specified time, and then reweighed. The amount of weight lost is taken as the amount of material decomposed during the time interval.

A number of variations on the litter bag procedure have been used. Jenny et al. (1949) used tin cans with the vegetation placed between sets of wire screens and glass-wool pads. Plastic-screen mesh bags were used by Wiegert and Evans (1964), while Koelling and Kucera (1965) used aluminumscreens stapled together. Latter and Cragg (1967) used nylon hair nets for bags, and Akhtar, et al. (1976) used "baskets" made of $7 \mathrm{~mm}$ mesh hardware cloth. Nylon bags for buried samples and fiberglass bags for aboveground samples were recommended by Swift and French (1972).

Clark (1970) states that "burial and retrieval of cellulose filter paper or herbage materials, in conjunction with gravimetry and ignition, has been found an operational simple procedure for studying microbial responses to the field environment."

Filter paper and herbage were, therefore, used as materials. Because herbage remains are deposited on the surface, surface and subsurface placements of the materials were tried.

This study covered a period of 3 years-September 1972 to September 1975. Results from the first year of study were reported by Ratliff (1976). This paper reports the combined 3-year results.

\section{Methods}

\section{The Study Sites}

In September, 1972, individual studies were started on five meadow sites in Sequoia National Park. The sites included a wide range of soil and moisture conditions and, in this paper, are referred to as Hair Sedge, Lake Shore, Chagoopa, Big Arroyo, and Sky Parlor.

Hair Sedge occupies a slope at an elevation of $3,094 \mathrm{~m}$ in the Little Five Lakes areas. Herbaceous vegetation there is dominated by short-hair sedge (Carex exserta Mkze.), which comprises $97 \%$ of the composition by point quadrat analysis. The soil is very 
shallow and rocky and dries rapidly following snowmelt.

Lake Shore, also in the little Five Lakes area, is dominated by shorthair (Calamagrostis breweri Thurb.) (38\%) and Carex subnigricans Stacey (29\%). The site is on a lake shore at 3,123 $\mathrm{m}$ and receives additional moisture from the lake and from seeps above. The soil is underlain by sand and boulders.

Chagoopa is in a large open meadow on Chagoopa Plateau at $3,048 \mathrm{~m}$. This site is dominated by shorthair which makes up $47 \%$ of the composition. The soil is gravelly, deep, friable, and well drained. Chagoopa receives no added moisture beyond normal precipitation.

Big Arroyo is a small opening at $2,760 \mathrm{~m}$ in Big Arroyo. Tufted hairgrass (Deschampsia caespitosa (L.) Beauv.) and Nevada rush (Juncus nevadensis Wats.) are the dominant species at this site. Nevada rush comprises $28 \%$ and tufted hairgrass comprises $23 \%$ of the vegetation. The soil is deep and appears to receive some moisture from subsurface flows.

Sky Parlor is in a large meadow on Chagoopa Pleateau at 2,736 $\mathrm{m}$. Beaked sedge (Carex rostrta Stokes.) is the dominant species and makes up $57 \%$ of the composition. The soil at Sky Parlor is deep and rich in organic matter. Water usually stands on the surface until mid- to late summer.

Except at Hair Sedge, decomposition at these sites is more dependent upon soil temperature than upon soil moisture. Kononova (1966) stated that decomposition intensity is greatest when temperatures are about $35^{\circ} \mathrm{C}$ and soil moisture is about $30 \%$ by weight. With the usually dry summers in the Sierra Nevada of California, soil moisture contents should be near minimum at the sites by September. Hair Sedge had less than $3 \%$ soil moisture at that time, although the other sites had percentages of soil moisture near or well above $30 \%$ in all years of the study. Thus, lack of moisture, although varying from year to year, is likely not a limiting factor to decomposition in most meadow types. At some sites-especially ones like Sky Parlor with soil moisture usually above 100 percent-decomposition may, however, be mostly anaerobic.

Soil temperatures at each of four depths-0, 5, 10, and 15 $\mathrm{cm}$-were mostly less than $20^{\circ} \mathrm{C}$ at all five sites in September. With adequate moisture, it is likely that decomposition is most rapid at the sites from mid-July to mid-August, given the elevations at which they are located. The soil at Hair Sedge will usually be dry about August 1. Hence, the main period of decomposition there is likely to be late July.

Except for occasional pack horse use, none of the meadow sites involved in this study has been grazed by livestock for many years.

\section{Experimental Design}

The experimental design at each site was a randomized complete block experiment repeated over 3 years. The linear model and computational methods for this design are described by Federer (1955).

Three transects were set out within each site. Each was representative of the site and was selected for uniformity in cover and species composition with other transects on the site. The reason for having the transects alike was to control those within-site variables which could mask the effects of yearly variations on decomposition.

One of the three transects on a site was randomly selected for each year of the study. Each year, 10 complete blocks were set out at $1-\mathrm{m}$ intervals along the transect for that year. Each block was $0.09 \mathrm{~m}^{2}$ in size ( 1 square foot). Blocking was used to control possible effects of microrelief and slope position on the results.

To each quarter of each block, one of the following combinations of type of sample material and position of placement was randomly assigned, giving a $2 \times 2$ factorial treatment design:

a. Filter paper buried $5 \mathrm{~cm}$ deep.

b. Filter paper unburied.

c. Native herbage buried $5 \mathrm{~cm}$ deep.

d. Native herbage unburied.

\section{Sample Material and Placement}

In general, the field and laboratory procedures used followed the recommendations of Swift and French (1972).

Each filter paper sample consisted of two weighed 9-cm circles of Whatman No. 1 filter paper in 1-2 mm mesh nylon net bags. All herbage on a block was clipped to the sod or soil surface and mixed. Two subsamples of that herbage were placed in nylon bags, weighed, and returned to the block. Remaining herbage from the block was taken to the laboratory to assess moisture and ash content.

The sod was carefully cut and lifted from those quarters of each block where samples were to be buried. After the samples were placed, the sod was put back and packed. Unburied samples were held with nails at each corner of the bags.

Samples were placed in September each year and recovered the following September. They were in place for from 362 to 365 days.

\section{Laboratory Procedures}

Percentages of moisture in the herbage samples were computed from the difference between field and oven-dry weights of material taken to the laboratory. Weights of the samples were also corrected for ash content, based on the ash in the laboratory samples. Filter papers were not corrected for ash because of the small amounts involved $(0.33 \mathrm{mg} /$ circle $)$. The resulting values were the initial sample weights.

Recovered sample weights were corrected for any adhering soil particles; e.g., mineral matter and soil organic matter. Mineral matter was determined by ashing the samples. A small soil sample taken at the 5-cm depth (at each block) was used to estimate the weight of organic matter associated with the mineral matter.

Samples were oven-dried at $60^{\circ} \mathrm{C}$ for 24 hours, and ashed at $600^{\circ} \mathrm{C}$ for 4 hours. Initial and net recovered weights were to two-place accuracy. Four-place accuracy was used in determining values from ashing.

\section{Statistical Procedures}

Several of the decomposition samples were destroyed by rodents or washed out of place. A minimum of five complete blocks occurred at Big Arroyo for 1972-73. Yearly and overall years analyses were made for each site. For the individual yearly analyses, all intact blocks occurring in a given year on a site were used. For the overall years analyses, complete blocks were chosen at random and dropped from those years with more than the minimum number of intact blocks. This approach was used in order to maintain randomness and to balance the data.

The best kind of material and/or placement to use may depend upon the kind of meadow. Between-site differences in decomposition rates were expected. In order to more clearly understand the results at each site and to eliminate a known source of variation, between-site comparisons were, therefore, not planned as part of the study. Results from each site were analyzed separately. The hypotheses of equality among treatment, year, and year-bytreatment means were tested by the $F$-ratio in analysis of variance. Treatment sums of squares in the over-all year's analyses were also broken into main and interaction effects for more detailed examination.

Interest was in all pairwise comparisons among the means. Tukey's w-procedure (Steel and Torrie 1960; Snedecor 1956) was used to separate means. Differences were at the $5 \%$ level of significance.

A sampling error problem related to the analysis deserves mention. At Sky Parlor, several of the unburied filter papers gained weight over the year in place. This problem was most serious in 1973-74 and has been observed in similar studies. Although the reasons for the phenomenon are not clear, we consider such samples to be valid. The negative decomposition values, therefore, were entered for analysis.

\section{Results and Discussion}

Weight Losses

On the basis of the individual yearly analyses, buried and 
Table 1. Percentages of original weights lost by filter paper and native herbage, buried and unburied, at five meadow sites in Squoia National Park, California, by sample year. (Individual analyses)

\begin{tabular}{|c|c|c|c|c|}
\hline \multirow[b]{3}{*}{ Sample year } & \multicolumn{4}{|c|}{ Material and placement } \\
\hline & \multicolumn{2}{|c|}{ Filter paper } & \multicolumn{2}{|c|}{ Herbage } \\
\hline & Buried & Unburied & Buried & Unburied \\
\hline & \multicolumn{4}{|c|}{ Hair Sedge } \\
\hline $1972-73$ & $54.20 \mathrm{a}^{1}$ & $28.90 \mathrm{~b}$ & $50.93 a$ & $54.61 \mathrm{a}$ \\
\hline $1973-74$ & $52.15 b c$ & $43.38 \mathrm{c}$ & $68.36 \mathrm{ab}$ & $77.79 a$ \\
\hline \multirow[t]{2}{*}{$1974-75$} & $21.54 \mathrm{~b}$ & $19.57 b$ & $47.76 \mathrm{a}$ & $60.74 a$ \\
\hline & \multicolumn{4}{|c|}{ Lake Shore } \\
\hline $1972-73$ & $22.10 \mathrm{~b}$ & $17.70 \mathrm{~b}$ & $49.02 \mathrm{a}$ & $50.00 \mathrm{a}$ \\
\hline \multirow{3}{*}{$\begin{array}{l}1973-74 \\
1974-75\end{array}$} & $25.03 b$ & $17.73 b$ & $5^{3} .82 \mathrm{a}$ & $55.14 \mathrm{a}$ \\
\hline & $27.97 b$ & $18.21 \mathrm{~b}$ & $49.04 \mathrm{a}$ & $49.71 \mathrm{a}$ \\
\hline & \multicolumn{4}{|c|}{ Chagoopa } \\
\hline $1972-73$ & $85.28 \mathrm{a}$ & $58.81 \mathrm{~b}$ & $64.20 \mathrm{~b}$ & $55.48 b$ \\
\hline $1973-74$ & $62.52 \mathrm{a}$ & $59.97 \mathrm{a}$ & $66.38 \mathrm{a}$ & $63.61 \mathrm{a}$ \\
\hline \multirow[t]{2}{*}{$1974-75$} & $57.93 \mathrm{a}$ & $39.02 \mathrm{a}$ & $48.62 \mathrm{a}$ & $52.34 \mathrm{a}$ \\
\hline & \multicolumn{4}{|c|}{ Big Arroyo } \\
\hline $1972-73$ & $90.61 \mathrm{a}$ & $51.46 \mathrm{~b}$ & $55.75 b$ & $52.34 b$ \\
\hline $1973-74$ & $80.54 a$ & $50.29 b$ & $49.28 b$ & $57.73 b$ \\
\hline \multirow[t]{2}{*}{$1974-75$} & $50.30 \mathrm{a}$ & $39.15 \mathrm{a}$ & $50.38 \mathrm{a}$ & $53.16 \mathrm{a}$ \\
\hline & \multicolumn{4}{|c|}{ Sky Parlor } \\
\hline $1972-73$ & $69.36 \mathrm{~b}$ & $12.0 \mathrm{lc}$ & $83.47 \mathrm{a}$ & $73.91 \mathrm{~b}$ \\
\hline $1973-74$ & $58.04 \mathrm{a}$ & $-3.19 b$ & $63.06 \mathrm{a}$ & $58.26 \mathrm{a}$ \\
\hline $1974-75$ & $74.48 \mathrm{a}$ & $26.83 b$ & $71.62 \mathrm{a}$ & $63.47 \mathrm{a}$ \\
\hline
\end{tabular}

I Row values followed by a like letter are not significantly different $(P=.95)$ by Tukcy's $w$-procedure.

unburied herbage samples gave equivalent results more often than buried and unburied filter papers. There was one significant within-year difference between weights lost by buried and unburied herbage samples (Table 1). In contrast, percentages of weight lost by buried and unburied filter papers were significantly different one or more years on all but one site.

Buried and unburied filter papers consistently gave lower percentages of weight loss than buried or unburied herbage at only one site (Table 1). Buried filter papers had greater losses than one or both herbage samples in one or two of the years at two sites. Losses from unburied filter papers sometimes equaled, but never exceeded, the losses from the herbage samples, and their losses were consistently less than for the herbage samples at three sites.

Microbial activity tends to be inversely related to carbon:nitrogen $(\mathrm{C}: \mathrm{N})$ ratio of the substrate. Nitrogen in herbage samples collected at about the same time of the year and on sites similar to those involved in this study averaged about 1.1 percent ${ }^{1}$. Compared with values given by Latter and Cragg (1967) and Gray and Biddlestone (1974), that percentage of nitrogen roughly translates to a $\mathrm{C}: \mathrm{N}$ ratio of from 43:1 to $45: 1$. The filter papers used were nearly pure cellulose. Hence, the less favorable environment for decomposition provided by its chemical make-up would explain some of the lower percentages of decomposition found with filter papers. Also, decomposition of herbage is underway before it reaches the soil, while the filter paper must be colonized. And, at least for the surface placement, more rapid drying of

${ }^{1}$ Unpublished data, Pacific Southwest Forest and Range Experiment Station, $2081 \mathrm{E}$ Sierra Ave., Fresno, Calif. 93710. the filter paper may reduce decomposition, as compared with herbage.

For all years (Fig. 1) there were no differences between percentage of weights lost by the herbage samples. Filter paper samples differed significantly at two sites. Buried filter papers differed from the herbage samples at only one site, but on three sites unburied filter papers decomposed less than the herbage samples.
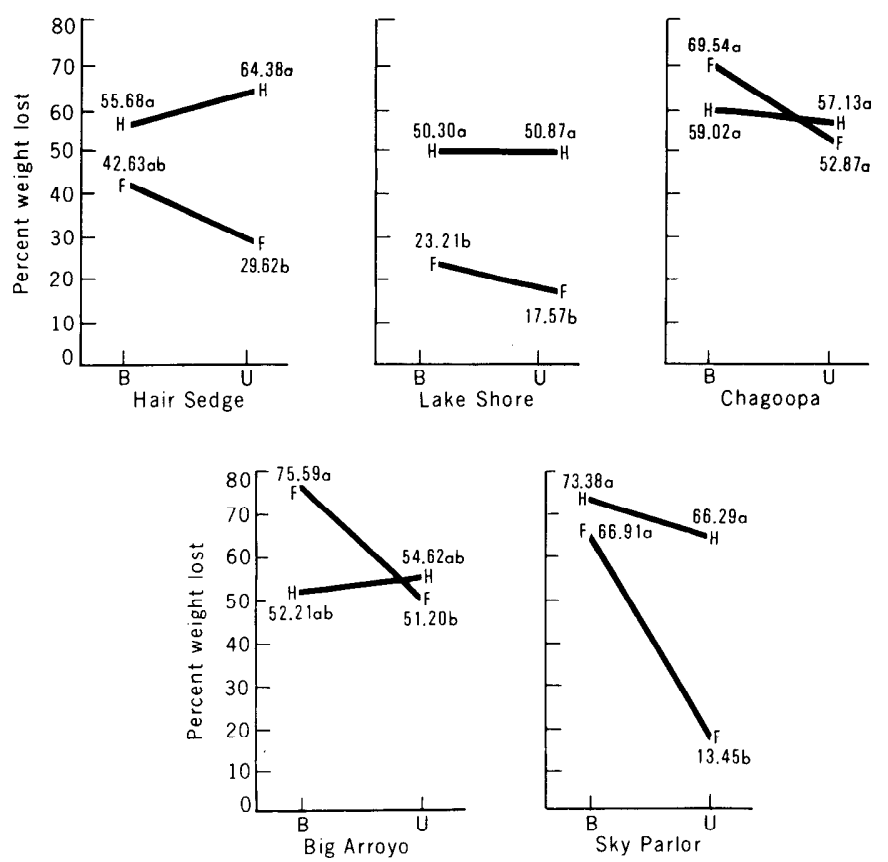

Fig. 1. Percentages of original weights lost and interaction effects for filter paper $(F)$ and herbage $(H)$, buried $(B)$ and unburied $(U)$ at five meadow sites in Sequoia National Park, California, 3-year averages. (Like letters within site indicate no difference $(\mathrm{P}=0.95)$ by Tukey's w-procedure.)

Interactions between type of material and placement (Fig. 1) were significant only at Big Arroyo and Sky Parlor. Whether significant or not, the direction of filter paper response was down (less decomposed) from the buried to unburied placements on all sites. Directions of response to surface placement differed between sites for the herbage samples, and the gradients were generally much less than for filter paper, e.g., the $2 \%$ increase compared with the $24 \%$ reduction of Big Arroyo. Thus, differences in responses of the filter paper samples to the placements were largely responsible for the interactions.

These results suggest that one may interchange the use of buried and unburied native herbage, but that interchange of buried and unburied filter papers would likely produce different results. Buried filter papcrs appear to give values equivalent to those of native herbage more often than do unburied filter papers. Use of unburied filter papers to estimate annual herbage decomposition, therefore, may not be advisable. But for some meadow sites it appears that buried filter papers may be a viable alternative to native herbage for estimating decomposition rates.

Year effects were significant at four sites, and year-bytreatment interactions (Fig. 2) were significant at all sites except Lake Shore and Chagoopa. Differences in treatment responses in 1972-73 appear to be largely responsible for the year-by-treatment interactions. However, 1973-74 appears to be responsible for the interaction at Big Arroyo. Regard- 

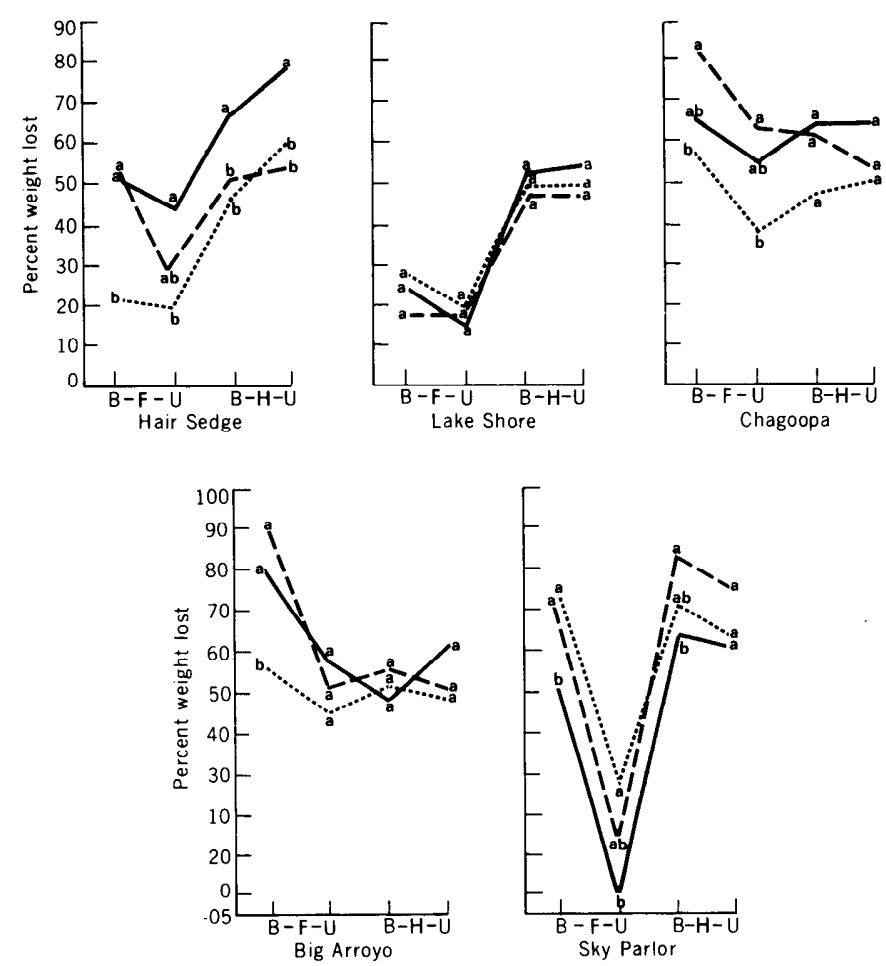

Fig. 2. Year-by-treatment means and interaction effects for filter paper $(F)$ and herbage $(H)$, buried $(B)$ and unburied $(U)$ for 1972-73 (_), 1973-74 (—), and 1974-75 (......) at five meadows sites in Sequoia National Park, California. (Years-by-treatments with like letters within site indicate no difference $(\mathrm{P}=0.95)$ by Tukey's w-procedure.)

less of the type of material and placement used, one should not assume independence from year effects, and these results clearly show the need for several years' data to firmly establish decomposition rates.

For each of the material and placement combinations the yearly means differed significantly on at least one site (Fig. 2 ). Unburied herbage showed a difference due to years only at Hair Sedge, while buried filter papers did so at all the sites except Lake Shore. Buried herbage and unburied filter papers were intermediate. Thus, it appears that buried filter paper is most affected by yearly differences in environmental factors and that unburied herbage is least affected.

\section{Standard Errors}

Results of the above analyses suggest use of buried or unburied native herbage as the best technique for estimating decomposition rates. Although the accuracy of the estimates remains unknown, their relative precisions given the same indication.

Treatment means standard errors for the individual years (Table 2), tended to be lower for herbage than for filter paper samples. The standard errors of the over-all years means were lower for the herbage samples at all sites. Maximum standard errors were $11.2,9.3,15.2$, and 16.6 percent of their yearly means (Table 1) for unburied and buried herbage and unburied and buried filter papers respectively. At the same sampling intensity, therefore, native herbage samples will likely give more precise estimates of decomposition rates than filter paper samples. Since the native herbage is the natural material, it is also resonable to assume that the estimates obtained with it will more closely reflect natural herbage decomposition rates.
Table 2. Standard errors of the percentages of sample weights lost by filter paper and native herbage, buried and unburied, at 5 meadow sites in Sequoia National Park, California, by year and over-all years.

\begin{tabular}{|c|c|c|c|c|}
\hline \multirow[b]{3}{*}{ Year } & \multicolumn{4}{|c|}{ Material and placement } \\
\hline & \multicolumn{2}{|c|}{ Filter paper } & \multicolumn{2}{|c|}{ Herbage } \\
\hline & Buried & Unburied & Buried & Unburied \\
\hline & \multicolumn{4}{|c|}{ Hair Sedge } \\
\hline $\begin{array}{l}1972-73 \\
1973-74\end{array}$ & $\begin{array}{l}7.32 \% \\
7.48\end{array}$ & $\begin{array}{l}4.72 \% \\
6.95\end{array}$ & $\begin{array}{l}4.72 \% \\
2.55\end{array}$ & $\begin{array}{l}4.19 \% \\
2.41\end{array}$ \\
\hline $1974-75$ & 7.92 & 2.82 & 4.37 & 3.55 \\
\hline All yrs. & 5.05 & 3.26 & 2.79 & 2.65 \\
\hline
\end{tabular}

$\begin{array}{lc}1972-73 & 4.97 \\ 1973-74 & 3.46 \\ 1974-75 & 7.93 \\ \text { All yrs. } & 3.16 \\ & \\ 1972-73 & 2.81 \\ 1973-74 & 10.35 \\ 1974-75 & 10.17 \\ \text { All yrs. } & 5.28\end{array}$

$1972-73$

1973-74

1974-75

All yrs.

1.90

4.52

4.48

$1972-73$

1973-74

1974-75

All yrs.

\subsection{8 \\ 8.50 \\ 4.68}

2.90
8.45

Lake Shore

$\begin{array}{lll}4.55 & 2.04 & 2.53 \\ 2.06 & 2.41 & 3.82 \\ 6.04 & 4.52 & 4.60 \\ 2.61 & 1.86 & 2.18\end{array}$

2.61

Chagoopa

$\begin{array}{lll}7.45 & 2.34 & 2.33 \\ 9.10 & 3.46 & 3.14 \\ 8.59 & 2.18 & 5.84 \\ 5.52 & 2.35 & 265\end{array}$

Big Arroyo

$\begin{array}{ccc}8.46 & 1.96 & 2.96 \\ 8.08 & 2.42 & 3.21 \\ 4.26 & 3.55 & 3.23 \\ 4.46 & 2.40 & 2.76\end{array}$

Sky Parlor

$\begin{array}{ll}1.35 & 1.44 \\ 2.60 & 1.96 \\ 2.54 & 5.16\end{array}$

3.65

2.17

2.20

\section{Conclusion}

From the first year's data, we concluded that unburied herbage samples had no advantage over buried herbage samples (Ratliff 1976). Statistically, results from the full 3 years of this study confirm that conclusion. Since the surface is where herbage is naturally deposited, surface placement of samples may give more accurate estimates of actual decomposition. Also, the time involved in burying samples makes surface placement more attractive. Thus, for estimation of herbage decomposition rates on individual sites, unburied native herbage is accepted as the most suitable of the techniques tried.

It can now be estimated that between about 50 and $70 \%$ of the average annual productions will decompose within 1 year at the study sites.

But how can such information be used by the land manager? The idea that the amount of the annual herbage production which should be ungrazed equals the average proportion decomposed annually was expressed by Ratliff (1976). Further study is needed to determine the validity of that idea and the relationship between decomposition rates and proper herbage use. Should it prove valid, however, 100 minus the rate would represent the degree of proper use. Using the rates of unburied herbage, degrees of proper use would be 36 for Hair Sedge, 49 for Lake Shore, 43 for Chagoopa, 45 for Big Arroyo, and 34 for Sky Parlor. 


\section{Literature Cited}

Akhtar, M.A., G.L. Rolfe, and L.E. Arnold. 1976. Litter decomposition in oak-hickory forests in southern Illinois. Agr. Exp. Sta., Univ. of Illinois at Urbana-Champaign. Forestry Res. Rep. No. 76-6. 3 p.

Clark, F.E. 1970. Decomposition of organic materials in grassland soil. US/IBP Grassland Biome Tech. Rep. No. 61. Colorado State Univ., Fort Collins. $12 \mathrm{p}$.

Dickinson, C.H., and G.J.F. Pugh (eds.). 1974. Biology of Plant Litter Decomposition. Vols. 1 and 2, Academic Press, London. 775 p.

Federer, W.T. 1955. Experimental Design Theory and Application. Macmillan Co., New York. p. 299-302.

Gray, K.R., and A.J. Biddlestone. 1974. Decomposition of urban waste. p. 743-775. In: Biology of Plant Litter Decomposition (Dickinson \& Pugh. eds.). Vol. 2, Academic Press, London.

Jenny, H., S.P. Gessel, and F.T. Bingham. 1949. Comparative study of decomposition rates of organic matter in temperate and tropical regions. Soil Sci. 68: 419-432.

Koelling, M.R., and C.L. Kucera. 1965. Dry matter losses and mineral leaching in bluestem standing crop litter. Ecology 46: 529-532.
Kononova, M.M. 1966. Soil Organic Matter Its Nature, Its Role in Soil Formation and Soil Fertility. 2nd. English ed. Pergamon Press, Oxford. $544 \mathrm{p}$.

Latter, P.M., and J.B. Cragg. 1967. The decomposition of Juncus squarrosus leaves and microbiological changes in the profile of juncus moor. J. Ecol. 55: 465-482.

Ratlif, R.D. 1976. Decomposition of filter paper and herbage in meadows of the high Sierra Nevada: preliminary results. U.S. Dep. Agr. Forest Serv. Res. Note PSW-308. Pacific Southwest Forest and Range Exp. Sta., Berkeley, Calif. 4 p.

Snedecor, G.W. 1956. Statistical Methods. Sth ed., Iowa State Univ. Press, Ames. p. 252-253.

Steel, R.G.D., and J.H. Torrie. 1960. Principles and Procedures of Statistics, with Special Reference to the Biological Sciences. McGraw Hill, New York. p. 109-110.

Swift, D.M., and N.R. French. 1972. Basic field data collection procedures for the Grassland Biome. US/IBP Grassland Biome Tech. Rep. No. 145. Colorado State Univ., Fort Collins. p. 68-69.

Wiegert, R.G., and F.C. Evans. 1964. Primary production and the disappearance of dead vegetation on an old field in southeastern Michigan. Ecology 45: 49-62. 